\title{
First record of Scartella itajobi Rangel and Mendes, 2009 (Perciformes: Blenniidae) from São Pedro e São Paulo Archipelago, Brazil
}

\author{
Paulo Augusto de Lima Filho ${ }^{1 *}$, Rodrigo Xavier Soares ${ }^{1}$, Wagner Franco Molina ${ }^{1}$ and Liana de \\ Figueiredo Mendes ${ }^{2}$ \\ 1 Universidade Federal do Rio Grande do Norte, Centro de Biociências, Departamento de Biologia Celular e Genética, Laboratório de Genética de \\ Recursos Marinhos. Avenida Salgado Filho, s/n. CEP 59078-970. Natal, RN, Brazil. \\ 2 Universidade Federal do Rio Grande do Norte, Centro de Biociências, Departamento de Botânica, Ecologia e Zoologia. Avenida Salgado Filho, s/n, \\ CEP 59078-970. Natal, RN, Brazil. \\ * Corresponding author. E-mail: pauloaugustoufrn@hotmail.com
}

\begin{abstract}
This article presents the first record of the blenniid Scartella itajobi in the São Pedro e São Paulo Archipelago, located off the state of Rio Grande do Norte, northeastern Brazil. As a result, the species distribution is extended $610 \mathrm{~km}$ northeast. The number of species of Blenniidae known to occur in São Pedro e São Paulo Archipelago is three, whereas the number of endemic fish species shared by São Pedro e São Paulo, Fernando de Noronha, and Rocas Atoll now stands at two.
\end{abstract}

São Pedro e São Paulo Archipelago (SPSPA) is a group of small islands and rocks located approximately $1000 \mathrm{~km}$ off the coast of Rio Grande do Norte State, northeastern Brazil (Figure 1). It shares about $80 \%$ of its fauna, including species of reef fishes, with the Brazilian coast. SPSPA is also considered as a low diversity fauna reservoir in the Brazilian Biogeographic Province (Edwards and Lubbock 1983; Floeter and Gasparini 2000; Joyeux et al. 2001; Feitoza et al. 2003).

Blenniidae is one of the most diverse families of Teleostei, with approximately 400 species in 56 genera (Eschmeyer and Fong 2011). However, only 10 species have been reported in Brazilian coastal waters, including two of which that were recently described from oceanic islands (Rangel and Mendes 2009). Two species of the family have been previously recorded in SPSPA: Ophioblennius trinitatis (Miranda Ribeiro 1919) a Pan-Atlantic species, and Entomacrodus vomerinus (Valenciennes 1836) a southwestern Atlantic species, both commonly found on the rocky coast and inland tide pools in SPSPA (Feitoza et al. 2003; Vaske Jr. et al. 2005).

A female specimen of Scartella itajobi (Figure 2) was collected in September 9, 2009 in Belmonte Island bay $\left(00^{\circ} 56^{\prime} \mathrm{N}, 29^{\circ} 26^{\prime} \mathrm{W}\right)$. The specimen was sheltered in a 40 $\mathrm{cm}$-deep rock crevice. It was fixed in formaldehyde and identified according to descriptions provided by Rangel and Mendes (2009). The specimen is now deposited in the Museu de Ciências Morfológicas at the Universidade Federal do Rio Grande do Norte (CPV-MCM 115).

In addition to $S$. itajobi, two other species of the genus occur in Brazil: Scartella cristata (Linnaeus 1758), which has an amphi-Atlantic distribution, and Scartella poiti (Rangel, Gasparini and Guimarães 2004) endemic to Trindade Island. These species display a cryptic behavior, are resistant to salt and temperature variations, and are frequently found in shallow waters and tide pools (Bauchot and Pras 1993; Mendes 2006).
The record of S. itajobi in SPSPA represents a distributional extension of approximately $610 \mathrm{~km}$ northeast from the supposedly northern limit of distribution of the species, which was thought to be Fernando de Noronha Archipelago. In addition, the number of reef fish species known to inhabit the SPSPA is now 61. This record, added to the geographic distribution of Pomacentridae Stegastes rocasensis (Emery 1972), changes to two the number of endemic species shared by SPSPA, Fernando de Noronha Archipelago and the Rocas Atoll (Rosa and Moura 1997; Vaske Jr. et al. 2005; Feitoza et al. 2003; Rangel and Mendes 2009).

Knowledge of species distribution is fundamental for inferences in ecology, zoogeography, biological management and conservation programs, particularly in areas of biological interest such as the Brazilian oceanic islands.

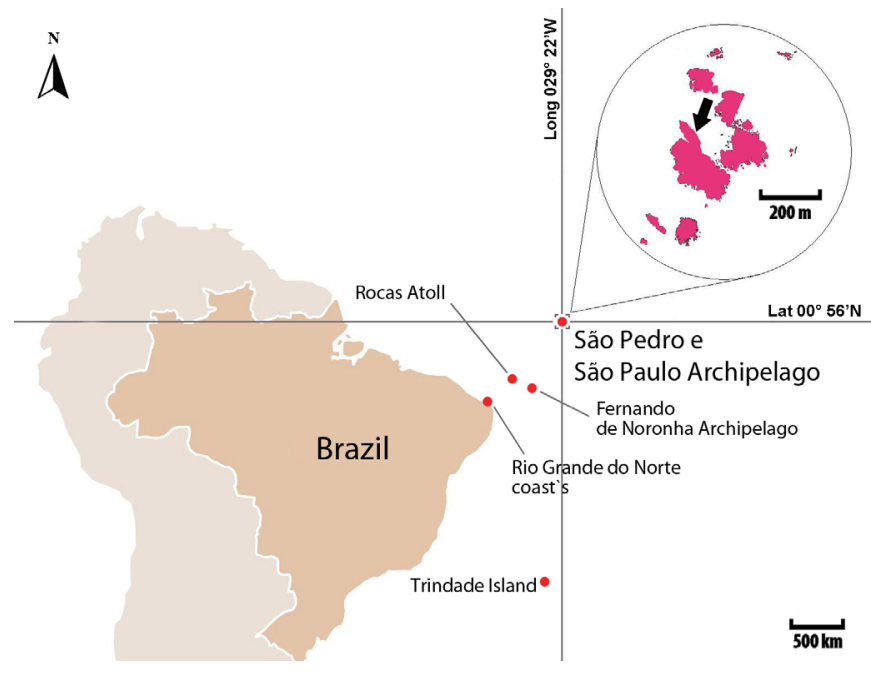

Figure 1. Map of Brazil and oceanic islands, with São Pedro e São Paulo Archipelago enlarged in the foreground. Arrow indicates the collection site of Scartella itajobi. 


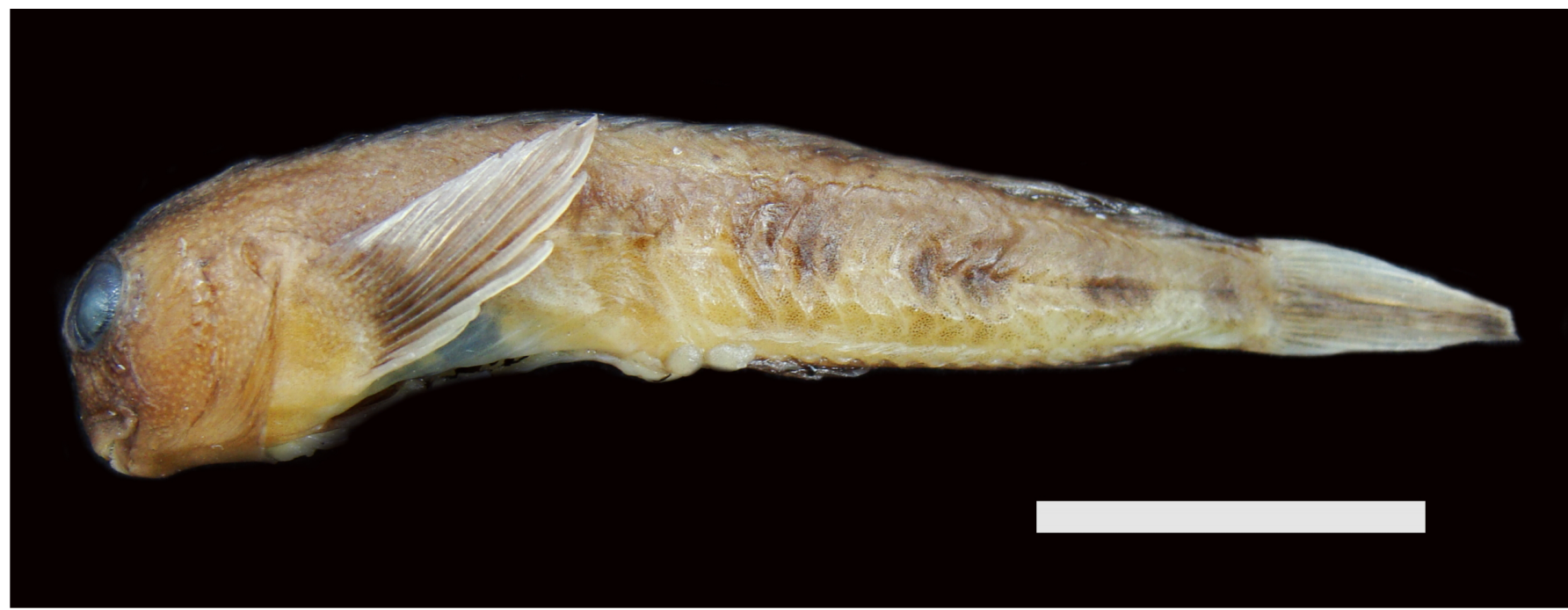

FIGURE 2. Female Scartella itajobi Rangel and Mendes, 2009 collected in São Pedro e São Paulo Archipelago. Scale = 1cm.

ACKNOWLEDGMENTS: We thank the Brazilian Navy and SECIRM (Secretaria da Comissão Interministerial para os Recursos do Mar) for logistic support, the ICMBio for the collection permit (19135-1), CNPq for financial support (556793/2009-9), the Museu de Ciências Morfológicas at the Universidade Federal do Rio Grande do Norte for curatorial assistance, and Luisa Moreira for helping during identification.

\section{LiTERATURE CiTED}

Bauchot, M.L. and A. Pras. 1993. Guía de los peces de mar de España y de Europa. Barcelona: Ediciones Omega. $432 \mathrm{p}$.

Edwards, A. and R. Lubbock. 1983. The ecology of Saint Paul's Rocks (Equatorial Atlantic). Journal of Zoology 200(1): 51-69.

Eschmeyer, W.N. and J.D. Fong. 2011. Species of Fishes by family/subfamily. Electronic Database accessible at http://research.calacademy.org/ research/ichthyology/catalog/SpeciesByFamily.asp Captured on 16 June 2011.

Feitoza, B.M., L.A. Rocha, O.J. Luiz Junior, S.R. Floeter and J.L. Gasparini. 2003. Reef fishes of St. Paul's Rocks: new records and notes on biology and zoogeography. Aqua Journal of Ichthyology and Aquatic Biology 7(2): 61-82.

Floeter, S.R. and J.L. Gasparini. 2000. The southwestern Atlantic reef fish fauna: composition and zoogeographic patterns. Journal of Fish Biology 56(5): 1099-1114.

Joyeux, J.C., S.R. Floeter, C.E.L. Ferreira and J.L. Gasparini. 2001 Biogeography of tropical reef fish: the South Atlantic puzzle. Journal of Biogeography 28(7): 831-841.
Mendes, L.F. 2006. História natural dos amborés e peixes-macaco (Actinopterygii: Blennioidei, Gobioidei) do Parque Nacional Marinho do Arquipélago de Fernando de Noronha, sob um enfoque comportamental. Revista Brasileira de Zoologia 23(3): 817-823.

Rangel, C.A. and L.F. Mendes. 2009. Review of the Blenniidae species from Fernando de Noronha Archipelago, Brazil, with description of a new species of Scartella (Teleostei: Blenniidae). Zootaxa 2006: 51-61.

Rangel, C.A., J.L. Gasparini and R.Z.P. Guimarães. 2004. A new species of combtooth-blenny Scartella Jordan, 1886 (Teleostei: Blenniidae) from Trindade Island, Brazil. Aqua, Journal of Ichthyology and Aquatic Biology 8(3): 89-96.

Rosa, R.S. and R.L. Moura. 1997. Visual assessment of reef fish community structure in the Atol das Rocas Biological Reserve, off Northeastern Brazil. Proceedings of the 8th International Coral Reef Symposium 8(1): 983-986.

Vaske, T., R.P. Lessa, M. de Nóbrega, S. Montealegre-Quijano, F. Santana J.L. and Bezerra. 2005. A checklist of fishes from the Saint Peter and Saint Paul Archipelago, Brazil. Journal of Applied Ichthyology 21(1): 75-79.

RECEIVED: February 2011

LAST REVISED: July 2011

ACCEPTED: July 2011

PUBLISHED ONLINE: September 2011

EDITORIAL RESPONSIBILITY: Michael Maia Mincarone 